\title{
CUSTOMS AND INCENTIVES IN CONTRACTS
}

\author{
Douglas W. Allen and Dean Lueck
}

\begin{abstract}
This article examines contractual practices that are often assumed customary. In particular it examines discreteness in agricultural contracts, and focuses on the distinction between the use of simple discrete fraction terms in cropshare contracts and the nearly continuous payment terms used in cash rent contracts. We show that the pattern of shares is best explained as a response to moral hazard problems spread over large numbers of inputs. A contracting model explains the pattern of shares, the difference in flexibility with cash rent contracts, and the lower bound on shares. Empirical analysis using micro data on over 3,000 contracts are used to test implications of the model. A wide range of support is found for a model based on moral hazard and measurement costs.
\end{abstract}

Key words: contracts, cropshare, custom, incentives.

\begin{abstract}
"Custom" has many meanings, and in economics may refer to a rule of thumb, a path dependency, a solution to a coordination game, or a nonmaximizing practice. The use of custom as an explanation of common practices has had a long hold on social scientists generally, and among economists in particular, because there are many observations in life that seem rigid and impervious to changes in fundamental economics forces. The allure of custom-based explanations has been especially prevalent in agriculture where it has been used to explain farming practices, contracts, and organizations that have remained stable for centuries. Most notably, custom has been the standard explanation for specific simple shares in contracts between farmers and landowners. For example, J.S. Mill observed: The relations, more especially, between the landowner and the cultivator, and the payments made by the former to the latter, are, in all states of society but the most modern, determined by the usage of the country.... But whether the proportion is twothirds or one-half, it is a fixed proportion; not variable from farm to farm, or from tenant to tenant. The custom of the country is the universal rule; nobody thinks of raising or lowering rents, of letting land on other than the customary conditions. Competition, as a regulator of rent, has no existence.
\end{abstract}

[1871, pp. 306-310]

Douglas W. Allen is Burnaby Mountain Professor at Simon Fraser University. Dean Lueck is Bartley P. Cardon Professor at the University of Arizona.

Thanks to Jorgen Mortenson for assistance with the data, and to David Andolfatto, Rob Innes, Christof Lulfesmann, two anonymous referees, and participants in numerous seminars for their comments. Research support was provided by the Cardon Endowment of Agricultural and Resource Economics at the University of Arizona.
The shares that Mill and others noticed in the nineteenth century often persist today. Across North America landowners and farmers still use simple fractions (such as, 1/2, $2 / 3,3 / 4, \ldots)$ to divide payments in these cropshare contracts, and these shares are seemingly resilient to changes in underlying economic forces, such as differences in land and labor quality. ${ }^{1}$ Using custom as an explanation may have begun with Mill, but it is also found among early agricultural economists such as Heady, ${ }^{2}$ and contemporary theorists such as Young and Burke (2001). ${ }^{3}$ In contrast to the traditional literature, however, Young and Burke develop a model of endogenous custom formation that does not rely on characteristics of preferences. Custom, in their model, serves to reduce bargaining costs by providing focal points for important contract terms.

Like Young and Burke, we explain the existence of rigid, customary practices, but to do this we develop a contracting model rather

\footnotetext{
${ }^{1}$ The same has been found in India and Africa (e.g., Bardhan 1984, Robertson 1987).

${ }^{2}$ Writing in the middle of the twentieth century, Heady states: Longstanding customs have grown up in the [farmland] rental market, with different shares paid by the tenant for different crops. Customary share rents over a large area of the Corn Belt include one-half of the corn and soybeans and two-fifths of the small grains... These variations in share rentals can be found in other regions of the United States and their bases are hard to determine. A possible hypothesis is that variations between crops are designed to give the tenant somewhat equal returns from resources devoted to different crops. ... Customs, regardless of their original foundation, are evidently of great importance in freezing share rentals in fixed proportions between crops.

[1952, pp. 605-608].

${ }^{3}$ Young and Burke examine share contracts in modern Illinois and state up front that "we shall argue that custom is a real force in setting contract terms, even in modern economies." (p. 560, 2001).
} 
than a dynamic bargaining model. ${ }^{4}$ Our model examines the observed discreteness in farmland contracts and focuses on the distinction between the use of simple discrete fractional terms in cropshare contracts and the nearly continuous payment terms used in cash rent contracts. In particular, we show that the pattern of shares is best explained as a response to moral hazard problems spread over large numbers of inputs, where inputs match in a competitive market. As a result, discrete rigid shares are the optimal solutions to a one shot game and are customary in name only. Thus, our use of the term "custom" contrasts with the modern economic meaning as a solution to a coordination problem (e.g., Schelling 1960). Our model explains the pattern of shares, the difference in flexibility with cash rent contracts, and the lower bound on cropshare terms. Empirical analysis using micro data on over 3,000 contracts are used to test implications of the model. A wide range of support is found for a model based on moral hazard and measurement costs.

\section{The Facts}

The customary contracting observed for over a century is more complicated than it first appears, and our objective is to explain the details. For example, most studies of customary practices of farm contracts have only examined half of the puzzle, namely, the observation that cropshares are limited to simple fractions. Farmland contracts, however, are found in two dominant forms: cropshare and cash rent. ${ }^{5}$ In cash rent contracts farmers pay landowners a per-acre dollar rental, whereas in share contracts the crop is split according to a share. ${ }^{6}$ In contrast to customary practice in share contracts, there would appear to be none in cash leases.

An example of the cropshare-cash rent distinction is demonstrated in figure 1 , which shows the distribution of shares for row crops (corn, sugar beets, soybeans, sorghum) in South Dakota and Nebraska for 1986 (Part A)

\footnotetext{
${ }^{4}$ Our model, though applied to agriculture, can easily be adapted to other settings. Furthermore, contractual rigidity has been noted outside of farmland leases by a number of economists, in areas such as real estate (Hsieh and Moretti 2003), oil and gas, and franchising (Blair and Lafontaine 2005).

${ }_{5}^{5}$ In fact, most leases across the United States are cash rent (57\% of leases), but this varies considerably across the country. See 1997 Census of Agriculture, Agricultural Economics and Land Ownership Survey (1999), table 99.

${ }^{6}$ Interestingly, cropshare contracts almost never contain lump sum side payments.
}

A. Cropshares

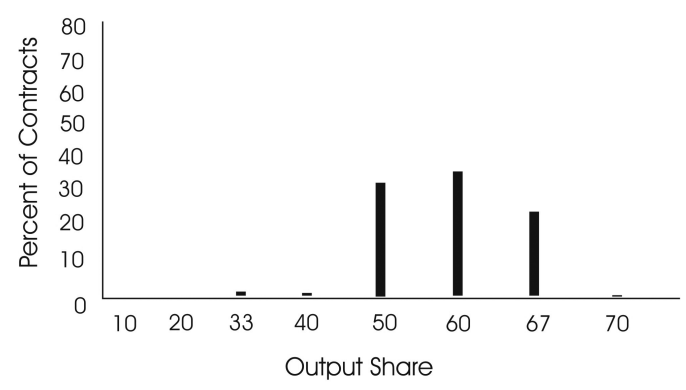

B. Cash Rents

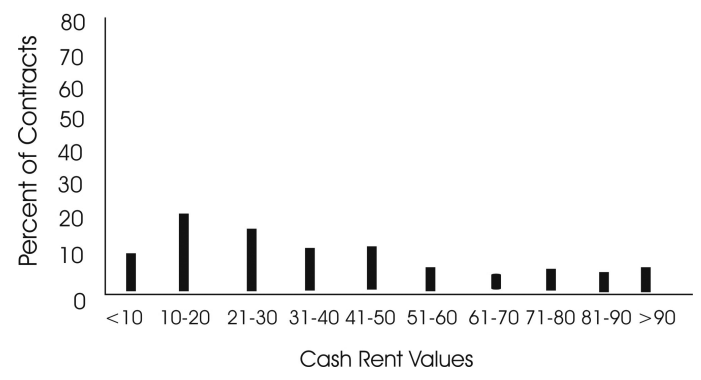

Row Crops, Nebraska/South Dakota, 1986

\section{Figure 1. Distribution of contract terms}

and the distribution of cash rent values for the same crops in the same states and year (Part B). For any given contract between a landowner and farmer, the soil quality, other inputs, and labor market conditions will vary considerably across the two states. Even so, Part A of figure 1 shows that three major shares $(1 / 2-1 / 2$, $3 / 5-2 / 5$, and $2 / 3-1 / 3$ ) account for over $94 \%$ of all contracts. The histogram, which shows that share terms are dominated by a few simple discrete fractions, is similar to those found in other locations and time periods (e.g., Young and Burke 2001). However, as we show later, depending on the crop, the actual share values can be different and will depend on the type of crop. Part B of figure 1, which shows the distribution of contract terms for cash rent contracts sharply with what is found for cropshare contracts. Though the crops, time period, and location are the same as the top graph, the distribution is nearly continuous unlike the discreteness found for cropshare terms. In fact because the bottom graph is drawn with the cash rent values collected into groups, it distorts the continuity of the true cash rent distribution. Indeed, there are over 100 different cash rent values, with $\$ 25$ per acre being the modal rent at $8.56 \%$ of contracts. The next most frequent cash rent value accounts for only $6.6 \%$ of contracts. 
Table 1. The Frequency of Cash Rent Contract Terms Across Regions

\begin{tabular}{lcccc}
\hline & \multicolumn{4}{c}{ Region (Date) } \\
\cline { 2 - 5 } & $\begin{array}{c}\text { British } \\
\text { Columbia } \\
(1979)\end{array}$ & $\begin{array}{c}\text { British } \\
\text { Columbia } \\
(1992)\end{array}$ & $\begin{array}{c}\text { Louisiana } \\
(1992)\end{array}$ & $\begin{array}{c}\text { Nebraska/ } \\
\text { South Dakota } \\
(1986)\end{array}$ \\
\hline Number of different cash rents & 98 & 59 & 45 & 140 \\
Modal frequency & $4.6 \%$ & $4.8 \%$ & $11.6 \%$ & $8.34 \%$ \\
Modal value(s)per acre & $\$ 60$ & $\$ 50,100,150$ & $\$ 50$ & $\$ 15$ \\
Percent cash rent & $59.1 \%$ & $73.7 \%$ & $36.8 \%$ & $43.03 \%$ \\
Total contracts & 592 & 171 & 513 & 1,831 \\
\hline
\end{tabular}

Table 2. The Frequency of Farmer Shares in Cropshare Contract Terms Across Regions

\begin{tabular}{|c|c|c|c|c|c|c|}
\hline \multirow[b]{2}{*}{$\begin{array}{l}\text { Fraction (Share) } \\
\text { to Farmer }(\%)\end{array}$} & \multicolumn{6}{|c|}{ Region (Date) } \\
\hline & $\begin{array}{l}\text { British } \\
\text { Columbia } \\
\text { (1979) }\end{array}$ & $\begin{array}{c}\text { British } \\
\text { Columbia } \\
\text { (1992) }\end{array}$ & $\begin{array}{l}\text { Louisiana } \\
\text { (1992) } \\
\text { (Frequenci }\end{array}$ & $\begin{array}{c}\text { Nebraska- } \\
\text { South Dakota } \\
(1986) \\
\text { s in Percent) }\end{array}$ & $\begin{array}{l}\text { Kansas } \\
(2000)\end{array}$ & $\begin{array}{l}\text { Illinois } \\
(1995)\end{array}$ \\
\hline $9 / 10(90)$ & 5 & 4.4 & 0.3 & 0.12 & 0 & 0 \\
\hline $17 / 20(85)$ & 7 & 20 & 0.6 & 0 & 0 & 0 \\
\hline $5 / 6(83.3)$ & 0 & 0 & 12.6 & 0 & $0-0.6$ & 0 \\
\hline $4 / 5(80)$ & 21.9 & 8.9 & 38.6 & 0.12 & $0-1.2$ & 0 \\
\hline $3 / 4(75)$ & 26 & 15.6 & 23.1 & 1.49 & $0.4-1.5$ & 0 \\
\hline $2 / 3(67)$ & 19.8 & 22.2 & 0.9 & 32.8 & $67.9-78.9$ & 9.7 \\
\hline $3 / 5(60)$ & 1.2 & 13.3 & 6.8 & 30.16 & $10.5-15.3$ & 6.7 \\
\hline $1 / 2(50)$ & 11.2 & 6.7 & 2.2 & 30.92 & $9.1-14.5$ & 82.3 \\
\hline $2 / 5(40)$ & 0 & 0 & 0 & 1.32 & $0-2.1$ & 2 \\
\hline \multicolumn{7}{|c|}{ Percent of Other Miscellaneous } \\
\hline Cropshares in sample & 7.9 & 8.9 & 14.9 & 5.9 & 0 & 1.3 \\
\hline Observations & 242 & 45 & 324 & 2,424 & 1,449 & 935 \\
\hline
\end{tabular}

Sources: For British Columbia, Louisiana, Nebraska, and South Dakota, see Data Appendix. For Illinois, see Young and Burke (2001). For Kansas, see Tsoodle and Wilson (2000, table 4) who have data on cropshare contracts for nonirrigated crops only. Tsoodle and Wilson only report data by region so the tables show the range across these regions instead of a statewide number. The totals may not sum to $100 \%$ because there are other shares not reported.

Examining various subsamples of crops, shares from different regions, and different contracts highlights other contract details. Consider cash rent contracts across different regions and times. Table 1 shows data from four surveys on the number of different per acre cash rent values for all crops, the modal frequency and values, and the percent of cash rent contracts. Two features of this table are worth emphasizing. First, there can be hundreds of different cash rent terms (i.e., per acre value) within a sample of contracts. Second, the modal frequencies for all data sets tend to be less than $10 \%$. Finally, this relationship is consistent across time and space.

Table 2 shows the frequency distributions of cropshares for all crops across the different regions and time periods of our samples. It shows that the distribution of shares (incorporating all crops) across these regions has three important characteristics. First, shares below 50-50 for the farmer are very rare-less than $2 \%$ in the three data sets, as though $50-50$ (or $1 / 2-1 / 2$ ) is a lower bound on the farmer's share. ${ }^{7}$ Second, these data show no universally dominant cropshare rate. ${ }^{8}$ From table 2

\footnotetext{
7 This point has been missed by the literature on optimal sharing.

${ }^{8}$ In any given place the optimal share might be very specific and rigid, giving the impression that all shares are fixed. Indeed, this has often led to an incorrect stylized fact among scholars of share contracting: namely that 50-50 sharing is the dominant sharing rule (Allen 1985, Neary and Winter 1995, and Eswaran and Kotwal 1985). The focus for 50-50 sharing often results from looking at a specific crop in a specific region where the 50-50 contract is simply the optimal share. For example, Heady (1952) saw mostly 50-50 sharing because his data were from the Corn Belt.Young and Burke (2001) also examine data from the Corn Belt.
} 
it is clear a variety of dominant share rates exist across different regions. For example, in Nebraska-South Dakota and Kansas 2/3's (to the farmer) is the dominant share and accounts for $32.8 \%$ and $68-79 \%$ of all shares, respectively. In Louisiana the share 4/5's makes up $39 \%$ of shares, whereas in British Columbia (1979) 3/4's makes up 26\%. Third, and finally, all of the shares are simple fractions (e.g., ratios of small whole numbers). In each case the shares are customary in that they are rigid locally, but vary across regions.

If we examine the cropshares for a specific crop across time and regions, then the dichotomy between shares and cash rents shown in figure 1 appears again. Figure 2 shows the share terms for corn across three regions and for three years. Although the shares vary, the pattern of discrete sharing is striking. In the plains states of South Dakota and Nebraska, shares for corn are similar to those found in the Corn Belt. In Louisiana, however, corn shares still take on a few simple fraction values, but these values are much different than in the north. In British Columbia the shares for corn are generally higher than those found on the plains, but they are also more widely distributed. ${ }^{9}$ Figure 2 demonstrates the problem of single state data sets. Though each graph shows discrete sharing with simple fractions, the actual fractions used vary considerably. ${ }^{10}$

It should be clear that there is a considerable amount of variation in contract terms found across different regions. It hardly seems satisfactory to say that the differences are explained by different customs. Our goal is to explain why share contracts appear inflexible relative to cash rent contracts, why shares take on simple fractions, why these fractions vary from crop to crop and location to location, and why shares seem to have a lower bound of 1/2. Given that these characteristics of sharing have existed for over 100 years, it seems likely that they have survived on efficiency grounds. We assume that the existing distributions of shares and cash rents are market clearing prices. More than one share and rent exist for a given crop because of the heterogeneities that are present in the crops, number of inputs, and moral hazard problems.

\footnotetext{
${ }^{9}$ We do not have enough corn share contracts in the British Columbia 1992 data to incorporate this into figure 2.

${ }^{10}$ Young and Burke (2001) present a similar graph (figure 1, p. 560) for Illinois (a corn state) where only three shares exist and $50-50$ accounts for over $80 \%$ of all contracts.
}
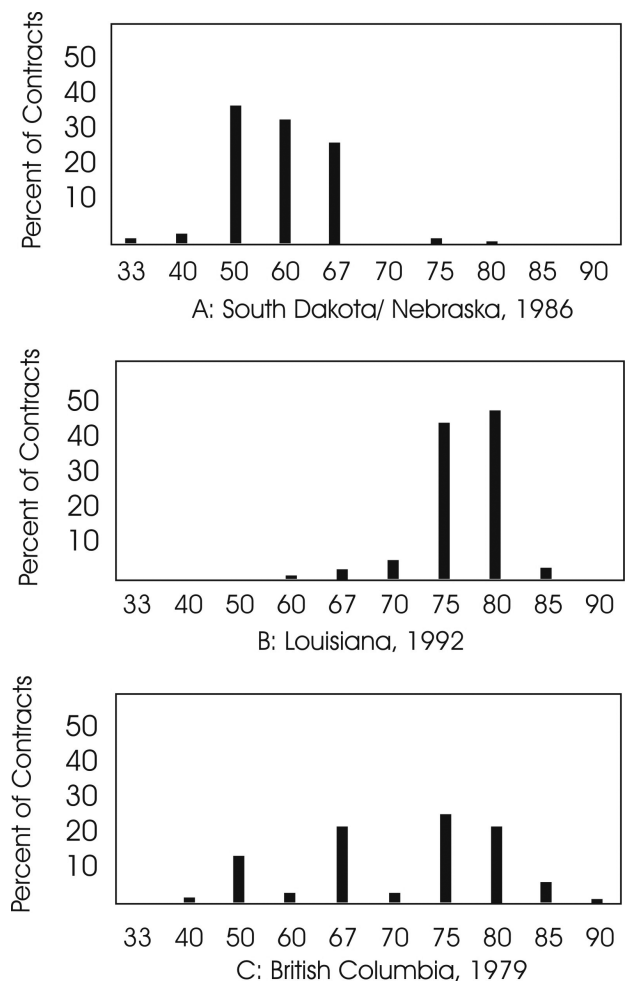

Figure 2. Share terms in farmland contracts for corn

\section{A Model of Customary Contract Structure}

Contracts have been modeled various ways within a vast literature, from classic principalagent models to bargaining models. Economic models of custom in contracts, however, are relatively scarce. ${ }^{11}$ As noted, Young and Burke (2001) develop a theory of customary practices in agricultural contracting in which discrete contract terms reduce contractual bargaining costs. Our approach differs and we derive implications about these contract terms and about the differences between cash rent and cropshare contracts. Our model has roots in Allen and Lueck (2002) and earlier work by Barzel (1997) and Holmstrom and Milgrom (1991). The intuition of the model suggests when soil exploitation is a serious problem cropshare contracts are used. When underreporting output is a serious problem, cash rent contracts are used.

To start, assume all parties are risk neutral and farming involves a number of inputs

\footnotetext{
${ }^{11}$ Akerlof (1980) and Romer (1984) are two early studies that generally show how customs can arise from maximizing behavior but neither focus on contracts per se.
} 
(initially set at two). Let $Q_{i}=h\left(e_{i}, l_{i}\right)+\theta_{i}$, where $Q_{i}$ is the harvested output (with unit price) produced on the $i$ th farm; $e_{i}$ is a composite input of farmer $i$ inputs, including labor time and effort, equipment, and other farming materials; $l_{i}$ is a composite input of noncontractible land attributes, such as fertility and moisture content; and $\theta_{i} \sim\left(0, \sigma_{i}^{2}\right)$ is a randomly distributed composite input that includes weather and pests. ${ }^{12}$ The inputs and output are subscripted with $i$ because farmer and landowner inputs vary in quality. Thus, the opportunity cost of the farmer's input is the competitive wage rate $w_{i}$ per unit of farmer's effort, and the opportunity cost of the unpriced land input is $r_{i}$ per unit. ${ }^{13}$ In a farmland cash rent contract the land is priced by the acre $(F)$, and this price is a sunk fixed cost to the farmer for the duration of the contract.

If contracts could be enforced without cost there would be no input distortion and no output measurement problem. With risk-neutral landowners and farmers, the expected profit from the farming operation is maximized, resulting in the employment of $e_{i}^{*}$ and $l_{i}^{*}$ units of farmer and landowner inputs. These first-best, full-information input levels are identical for the cropshare and cash rent contracts and satisfy the standard conditions that marginal products equal marginal costs for both inputs. When land attributes are noncontractible, however, the input choices will be second-best. In either contract, farmers have an incentive to exploit the land's unpriced attribute $\left(l_{i}\right)$ because they do not face the full costs, $r_{i}$. In addition, farmers have an incentive to under-report the output in the cropshare contract.

When farmer and landowner inputs vary in quality, matching will take place in equilibrium. We solve for this equilibrium in two stages. First, we consider what outcomes result in an arbitrary matching of farmers and landowners. Second, we impose a matching condition to determine the equilibrium. For this we drop the subscript $i$ to economize on notation.

\footnotetext{
${ }^{12}$ Given the risk neutrality, the purpose of $\theta$ is to prevent the parties from deducing input levels from the observable output. We assume $h_{e e}, h_{l l}<0$, and $h_{e l}=0$. This latter restriction is necessary to generate our Proposition (3) regarding input sharing.

${ }^{13}$ We assume that the costs of both inputs are constant. This is a necessary assumption to generate all of the propositions in the paper.
}

\section{Cropshare and Cash Rent Contracts}

For the cash rent contract, the farmer hires a tract of farmland for a lump sum fee paid prior to the growing season. He owns the entire crop and chooses his inputs to maximize expected profit. Because the farmer does not own the land and because the land attributes are noncontractible, he does not face the true opportunity cost $r$ of using the land attributes. We denote the reduced costs he faces as $r / m<r$, where $m \in(1,+\infty)$ is a measure of the degree of land use moral hazard. ${ }^{14}$ Thus, the farmer's objective is

$$
\max _{e, l} E\left(\Pi^{r}\right)=h(e, l)-w e-(r / m) l-F
$$

where $F$ is the farmer's rent for the land. The second-best solutions $e^{r}$ and $l^{r}$ satisfy: $h_{e}\left(e^{r}\right) \equiv w$ and $h_{l}\left(l^{r}\right) \equiv r / m$, assuming $h_{e l}=0$. The farmer's effort level is identical to the firstbest optimum; that is, $e^{r}=e^{*}$. However because $r / m<r, l^{r}>l^{*}$, the land is over-worked because the farmer does not face the full cost of using the land's attributes.

In a cropshare contract, the farmer has exclusive use of the plot of land and does not pay the landowner prior to production. At harvest, the crop is divided between the farmer and landowner, with the farmer receiving $s Q$ and the landowner receiving $(1-s) Q$, where $s \in[0$, 1]. An important assumption in our model, and one that reflects the reality of cropshare contracts, is that there is no side payment made between the farmer and the landowner. The only instrument used to divide the output is the share. The farmer bears all costs of the variable inputs except the differential cost of the land's unpriced attributes. The farmer's objective is

$$
\max _{e, l} E\left(\Pi^{s}\right)=s[h(e, l)]-w e-(r / m) l .
$$

The second-best solutions $e^{s}$ and $l^{s}$ satisfy: $s h_{e}\left(e^{s}\right) \equiv w$ and $\operatorname{sh}_{l}\left(l^{s}\right) \equiv r / m$. These solutions indicate the farmer supplies too few of his inputs because he must share the output with the landowner; that is, $e^{s}<e^{*}$. As with cash rent, the farmer overuses the land attributes, or $l^{s}>l^{*}$; however because $l^{r}>l^{s}>l^{*}$, the use of the land is less excessive than it is with cash rent. This means a share contract still provides the farmer with an incentive to overuse the land, although this incentive is not as powerful

\footnotetext{
${ }^{14}$ When $m=1$ there is no moral hazard.
} 


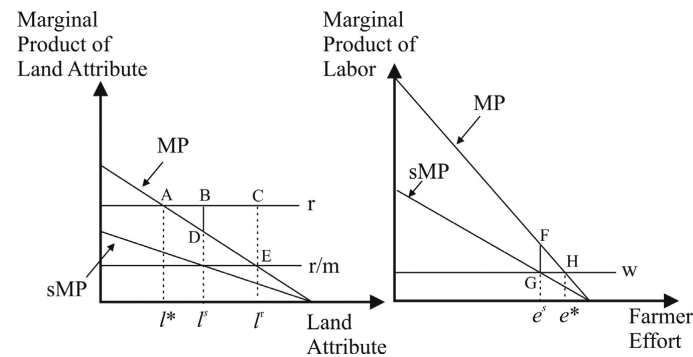

Figure 3. Optimal sharing rule

as it is with the cash rent contract. ${ }^{15}$ Both types of contracts are second best, and the contract that yields the highest joint rent is chosen. ${ }^{16}$

Still assuming that a random farmer and landowner are contracting together, the optimal share results from maximizing the value of the cropshare contract through the choice of share, conditional on the choice functions from the solution to equation (2):

$$
\max _{s} E(\Pi)=h\left(e^{s}, l^{s}\right)-w e^{s}-r l^{s}
$$

This leads to the following first-order condition:

$$
\frac{\partial l^{s}}{\partial s}\left[r-h_{l}\left[l^{s}(s)\right]\right]=\frac{\partial e^{s}}{\partial s}\left[h_{e}\left[e^{s}(s)\right]-w\right]
$$

Equation (4) is essentially an incentive constraint, and states the share is chosen such that the marginal benefit of changing the share $\left(\partial l^{s} / \partial s\left[r-h_{l}\left[l^{s}(s)\right]\right]\right)$ just equals the marginal $\operatorname{cost}\left(\partial e^{s} / \partial s\left[h_{e}\left[e^{s}(s)\right]-w\right]\right)$. For example, if the share to the farmer is reduced, the reduced soil exploitation is the benefit, whereas the reduced labor effort is the cost. Figure 3 demonstrates the equilibrium of the model, and also shows the first-best input levels $e^{*}$ and $l^{*}$. In a cash rent contract the farmer faces reduced costs of using land attributes and chooses $l^{r}$, resulting in a deadweight cost of ACE. In a share contract the perceived marginal products to the farmer are lower and, therefore, he reduces the amount of both inputs used to $e^{s}$ and $l^{s}$, resulting in two deadweight costs, ABD

\footnotetext{
${ }^{15}$ The expected rent to the landowner is $E\left(\Pi^{s}\left(e^{s}, l^{s}\right)\right)$, which means there is profit sharing under the cropshare contract. This is inevitable when there is no side payment. In the cash rent contract the expected profits are $E\left(\Pi^{r}\left(e^{r}, l^{r}\right)\right)$. We assume these are shared in a fixed proportion such that the cash rent contract is competitive with the cropshare contract.

${ }^{16}$ Because farmers have an incentive to under-report shared crops, the cropshare contract does not always dominate the cash rent contract. Allen and Lueck (2002) discuss this issue at length.
}

and FGH. The equilibrium share occurs when the distances BD and FG are equal.

\section{Optimal Discrete Share Contracts}

Equation (4) does not yield specific equilibrium shares, nor does it predict shares equal to simple fractions. Depending on the production function, many shares are possible. However, competition among landowners and among farmers leads to matching behavior that does imply simple fractions. When side payments are not used in share contracts, matching is very important. Low-quality farmers prefer to match with high-quality landowners because their incomes are higher. ${ }^{17}$ However, they will be unsuccessful because higher quality farmers will outbid low-quality farmers by offering landowners more income if matched with them. This result follows not from any complementarities between farmers and landowners, but from trying to maximize the joint wealth of the farm in light of the incentive problem caused by sharing. Were side payments common in share contracts, it would be possible for low-quality inputs to match with high-quality ones by offering a compensating side payment. However, with only a share to adjust (and adjust along the lines of equation (4)), the lowquality inputs cannot compete against higher quality ones. Thus, in our model the equilibrium has perfect assortative matching.

There are a number of ways to generate assortative matching for the condition in equation (4). One sufficient method is to recognize that if equally productive inputs match in equilibrium then the farmer adjusts both inputs equally in response to changes in the share. ${ }^{18}$ That is, the contracting parties match such that the derivatives $\partial e^{s} / \partial s$ and $\partial l^{s} / \partial s$ are equal. In general, the functions $\partial e^{s} / \partial s$ and $\partial l^{s} / \partial s$ depend on the production function, the input prices, and the share. However, if equally productive inputs match together then they behave

\footnotetext{
${ }^{17}$ We show later that in our model an increase in the productivity of one input may not even lead to an adjusted share under equation (4), hence the lower quality input is unambiguously better off matching with a higher quality input. Allen (1992) shows that, even when the share adjusts with quality, the lower quality input is still better off matching with the high-quality input. Essentially, when no side payment is used, the single share cannot solve both an incentive constraint and a rationality constraint unless there is equal matching. Hence competition among the various qualities of inputs leads to equal sharing and matching. Recent work by Ackerberg and Botticini (2002) suggests farmers and landowners may match on risk characteristics as well. The marriage literature has found strong empirical evidence that husbands and wives (who share marital output) match assortatively (e.g., Lam 1998).

${ }^{18}$ This assumes the inputs are equally productive in total and at the margin.
} 
Table 3. Optimal Shares for Given $m$

\begin{tabular}{cllllc}
\hline$m$ & 2 & 3 & 4 & 5 & 10 \\
\hline$s$ & 0.75 & 0.67 & 0.625 & 0.60 & 0.50
\end{tabular}

the same with respect to the share. ${ }^{19}$ As a result, the optimal sharing rule from equation (4) becomes

$$
s^{*}=\frac{w+r / m}{w+r} .
$$

But assortative matching has another implication. If farmers and landowners match along quality lines, then their opportunity costs must be the same; that is, $w_{i}=r_{i}$. This generates the first proposition:

PROPOSITION 1. When inputs match assortatively, the optimal share is given by

$$
s^{*}=\frac{1}{2}+\frac{1}{2 m} .
$$

With two inputs the share is simply a function of the degree of moral hazard, $m$. If $m$ takes on small values $(m<2)$, then sharing is unlikely and farmers and landowners cash rent (Allen and Lueck 2002). If $m$ is a continuous variable, then any share between 3/4 and 1/2 is possible with two inputs. However, for large values of $m$, the optimal share asymptotically approaches $50 \%$. Thus, our model of cropshare choice based on a simple moral hazard problem, when combined with market matching pressures, explains the existence of the 1/2 lower bound. ${ }^{20}$

\footnotetext{
${ }^{19}$ Although not part of our model, equal matching may also solve an information problem for farmers. In practice farmers do not precisely know their production function, and often use crude rules of thumb. Through experience landowners have rough ideas of what a yield should be, rough ideas of how much effort, seed, fertilizer, and chemicals are being used, and rough ideas of the crop, weather, and pest conditions. When inputs match assortatively the farmer only has to adjust the inputs the same, rather than figuring out how they should adjust differently.

${ }^{20}$ If one is willing to make an extra assumption, then the two input case can explain all discrete shares. If farmers and landowners have beliefs about $m$ as a discrete parameter because information on production is costly or because there are cognitive difficulties with continuous decimals, equation (6) yields a set of shares remarkably similar to those found in the data. These shares are shown in table 3. The potential loss of being wrong from rounding to whole values of $m$ is likely to be of second-order smallness. This result comes from the Envelope theorem that states small deviations from an optimum lead to insignificant losses of value (Akerlof and Yellen 1985). For example, suppose the value of $m$ is 2.6, but both the farmer and landowner round up to $m=3$. The optimal share for $m-2.6$ would be 0.69 , but the farmer and landowner would contract at $2 / 3$ or 0.67 . This lower
}

Equation (5) was derived under the assumption there were only two inputs (farmer effort, land attributes) in the production function. It is possible to consider additional inputs such as seed and fertilizer. Furthermore, an input like labor effort could be broken into specific tasks, which could be considered different inputs. For example, pruning and planting are different tasks, which could be considered different inputs. For example, if there is a third input $k$, and if the cost of the third input is $c$, then equation (5) becomes

$$
s^{*}=\frac{w+c+r / m}{w+c+r}
$$

under the assumption that the third input also matches along quality dimensions and, therefore, has a response to changes in the share equal to the other inputs. Again, if the input prices are also equalized through matching, then for three inputs equation (7) simply becomes $s^{*}=2 / 3+1 / 3 m$, with four inputs $s^{*}=$ $3 / 4+1 / 4 m$, and so on. In other words, with more inputs or tasks, the lower bound on the optimal share increases. Thus, we have our second proposition:

PROPOSITION 2. When the number of inputs (or tasks) increases the lower bound of the optimal share increases by discrete units, and is given by $(n-1) / n$ where $n$ is the number of inputs (or tasks).

Generally speaking, cropshare contracts are chosen when $m$ is large (Allen and Lueck 2002). This means the optimal share will tend to be the lower bound. The shares we observe then $(1 / 2,2 / 3,3 / 4, \ldots)$, are the optimal lower bounds when the number of unshared inputs increase.

\section{Input Sharing}

Input sharing terms are a crucial, but often ignored, feature of cropshare contracts and are an important determinant of the structure of cropshare contracts. Input sharing increases overall contract efficiency by better aligning the net returns to inputs choice, but comes at the cost of measurement and

share would mean less effort and land attributes could be used, but at the margin these losses and gains would offset each other because in equilibrium they are equal. There would be some loss in the value of the contract, but it would be of second-order smallness. Considering all of the unknowns in farming and the large role of Nature, assuming farmers and landowners think about moral hazard in discrete terms seems a minor assumption. 
enforcement of input cost over reporting (Allen and Lueck 1993, 2002). Two features of input sharing are important for this study. First, the data show that labor effort and land attribute costs are never shared, which implies a minimum of two unshared inputs. Shared inputs include things like fertilizer, seed, and fuel. ${ }^{21}$ Second, when input costs are shared, they are always shared in the same proportion as the output (Allen and Lueck 1993, 2002). When input costs are shared proportionately there is no distortion created for those inputs, and in terms of the optimal output share, it is given by equation (4). In other words, input sharing creates a situation where it is as if there were only two inputs. This means the lower bound on the optimal share will become $1 / 2$. Thus, we have a third proposition.

PROPOSITION 3. When inputs are shared, the output share is more likely 50-50.

\section{Discrete Cropshares and Internal Flexibility}

Compared to cropshare agreements cash rent contract terms have a much more continuous distribution of values and thus would appear to be more responsive to basic economic parameters. Yet this contractual discreteness in cropshares belies an internal flexibility within the contract structure that allows it also to respond to economic parameters. We examine this issue for both contract types in this section.

Cash rent contracts are more likely to occur when farmers are unable to exploit the soil (Allen and Lueck 2002). This implies $m$ is relatively small, and the cropshare to the farmers is 1 . The optimal cash rent is given by

$$
\Pi^{r}=h\left(e^{r}, l^{r}\right)-w e^{r}-(r / m) l^{r}-F .
$$

This function continuously depends on the production function, input costs, and the degree of moral hazard, implying that there is no discreteness in the rental rate. Unlike the share contract, the cash rent contract has no built-in adjustment to changes in prices, costs, and other economic parameters. For a given per acre lease rate, any increase in land productivity accrues to the farmer as a pure rent.

\footnotetext{
${ }^{21}$ Carmona and Simpson (1999) find that when 19th century Catalan vineyard share contracts introduced input cost sharing, the farmer's share declined.
}

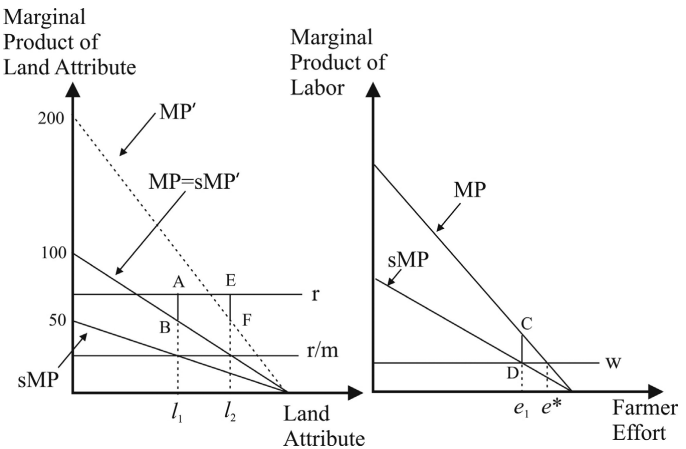

Figure 4. Optimal shares and land quality

Of course, this means that a change in land quality will be followed by a change in the rent per acre.

In a share contract, however, there is a different mechanism. Consider what happens to the optimal share when there is an increase in land productivity. Figure 4 shows a specific example, again assuming linear marginal productivity $(M P)$ and $\partial e^{s} / \partial s=\partial l^{s} / \partial s$. The solid lines show an initial equilibrium where $l_{1}$ and $e_{1}$ are the equilibrium values of land attribute use and farmer effort. These are determined when distances $\mathrm{AB}$ and $\mathrm{CD}$ are equal. Now suppose the marginal product of land doubles to $M P^{\prime}$. The first-order condition for land use before the productivity increase is $r / m \equiv s M P\left(l_{1}\right)$. The first-order condition after the increase in productivity is $r / m \equiv s M P^{\prime}\left(l_{2}\right)$. It thus follows that $M P^{\prime}\left(l_{2}\right) \equiv M P\left(l_{1}\right)$. This equality is independent of the share and implies there is no change in the optimal share following the change in land attribute productivity.

There are, however, two internal changes that arise in a cropshare contract as a result of the increase in the marginal product of land. First, the income to the landowner increases when the marginal product of land increases. The new gross income is $\int_{0}^{l_{2}}\left(M P^{\prime}-s M P^{\prime}\right) d l$, which is considerably larger than the old gross income $\int_{0}^{l_{1}}(M P-s M P) d l$. Second, there is more of the productive input used. This is the "built-in" flexibility of a cropshare contract. ${ }^{22}$ Even though a farmer and landowner may approximate the exact sharing equation and use customary shares, their incomes still adjust when economic parameters change. On the other hand, the cash rent contract does

\footnotetext{
${ }^{22}$ This built-in adjustment occurs even without matching. Of course, competition among inputs would mean that the increase in land productivity would be followed by a matching with higher quality labor effort.
} 
not have this feature. Changes in any productivity parameter change incomes through changes in the per acre rental price. In the example before, the cash rent will change as a result of the change in land productivity. Thus, these contracts are more continuous in their contracted rental terms, which leads to our final proposition.

PROPOSITION 4. Cash rent contract terms are more continuous than are the contract terms for share contracts.

This seemingly obvious point is worth raising because it has been often missed. The dominant view is that rigid and unresponsive shares are an economic puzzle (Allen 1985, Newberry and Stiglitz 1979, Young and Burke 2001). ${ }^{23}$ In general, the cropshare contract's ability to automatically adjust incomes in light of changing parameters either partially or totally offsets these changes. This implies that cropshare terms are more likely to be discrete and thus appear to be resistant to changes in fundamentals, even though the incomes to the parties are internally adjusting to the parameters.

\section{Empirical Analysis}

Our moral hazard model of cropshare structure has generated four predictions. In particular, cropshare terms take on the values given by equation (6) when there are two inputs; the lower bound increases with the number of inputs; 50-50 sharing is more likely with input sharing; and the distribution of cash rent contract terms is more continuous than cropshare contract terms. In this section, we test these propositions using data from British Columbia, Louisiana, and the plains states of Nebraska and South Dakota. Our empirical analysis is atypical because we rely on an analysis of the distributions of share and contract rents rather than estimations of regression equations.

\footnotetext{
${ }^{23}$ Young and Burke (2001) deal with this issue in the most detail and use the observation of fixed shares to motivate their bargaining theory. For them, the puzzle is that inflexibility allows farmers to capture landowner rents. They then go on to explain how this cannot be accounted for by labor mobility, contract adjustments, input sharing, or matching, and conclude custom must be the explanation. Still their empirical discussion is mostly casual and difficult to refute. In our model, changes in productivity do not lead to changes in shares, but do lead to changes in income. Equilibrium is maintained through matching. If changes in land productivity were correlated with some change in moral hazard or the number of inputs, then a change in share would occur. For example, a change in land productivity could induce a change in the major crop, which could alter the number of tasks, and lead to a change in the share.
}

We use four different data sets on farmland contracts in the empirical work that follows. These data are described in more detail in the Appendix. The first data set comes from the 1979 British Columbia landowner-farmer contracts survey. These data were collected by telephone and include 378 observations on farmland contracts. The second data set contains over 4,000 observations from the Great Plains states of Nebraska and South Dakota. These data come from the 1986 Nebraska and South Dakota Leasing Survey conducted by South Dakota State University. The third data set comes from the 1992 British Columbia Farmland Ownership and Leasing Survey and includes 460 observations on contracts. The fourth and final data set comes from the 1992 Louisiana Farmland Ownership and Leasing Survey and includes 530 observations on contracts. We also make use of some aggregated data from Illinois and Kansas.

\section{The Cropshare Lower Bound}

Proposition 1 states that cropshare contracts have an absolute lower bound. In the simplest case of two inputs the lower bound value is $50-50$ or $1 / 2-1 / 2$, and with more inputs the lower bound increases by simple fractions. A simple test of Proposition 1 is to examine the frequency of cropshare contracts that provide the farmer less than one-half of the crops. Table 4 shows the frequencies for the four data sets and breaks them down by crop. In the 1992 data sets from British Columbia and Louisiana there are no cases with cropshare less than 50-50. In the 1979 British Columbia data the only cases with share less than 50-50 are for corn $(0.9 \%)$ and hay-alfalfa $(3.0 \%)$. Only in the 1986 data from Nebraska-South Dakota do we find a small fraction of shares below $50-50 .{ }^{24}$ The information in table 4 strongly supports the proposition of a cropshare lower bound.

\section{Changes in the Number of Inputs}

Proposition 2 says that as the number of inputs increases the lower bound of the optimal

\footnotetext{
${ }^{24}$ It is our view that the higher numbers for Nebraska and South Dakota are likely recording errors. This was the only survey given to both landowners and farmers. The respondents were supposed to write down the share to the farmer, but it is conceivable some landowners wrote down their own share. This view of a data entry mistake is consistent with this in that when shares below $1 / 2$ arise in this data they almost always are the complements to two common larger shares (e.g., 1/3, 2/5). Regardless, even in the NebraskaSouth Dakota data, shares below $1 / 2$ are insignificant in number.
} 
Table 4. Frequency of Cropshares Less Than 1/2

\begin{tabular}{lcccc}
\hline \multicolumn{4}{c}{ Data Set } \\
\cline { 2 - 5 } & $\begin{array}{c}\text { Nebraska/ } \\
\text { South Dakota } \\
\text { (1986) }\end{array}$ & $\begin{array}{c}\text { Louisiana } \\
(1992) \\
\text { Crop }\end{array}$ & $\begin{array}{c}\text { British } \\
\text { Columbia } \\
(1992)\end{array}$ & $\begin{array}{c}\text { British } \\
\text { Columbia } \\
(1979)\end{array}$ \\
\hline Barley & 3.9 & & 0.0 & 0.0 \\
Oats & 2.08 & 0.0 & 0.0 & 0.0 \\
Wheat & 3.15 & 0.0 & 0.0 & 0.0 \\
Corn & 3.41 & & 0.0 & 0.0 \\
Hay/Alfalfa & 3.06 & & & 0.0 \\
Apples & & & & 0.0 \\
Pears & & 0.9 & 0.0 \\
Peaches & & 0.6 & \\
Cherries & & 0.0 & \\
Rice & 3.1 & 0.0 & & \\
Soy & & 0.0 & & \\
Cotton & & & & \\
Sugar & & & & \\
Milo & 4.1 & & & \\
\hline
\end{tabular}

Sources: See Appendix.

Table 5. The Frequency of Share to Farmer in Cropshare Contracts by Crop

\begin{tabular}{|c|c|c|c|c|c|c|}
\hline \multirow[b]{2}{*}{$\begin{array}{l}\text { Share to } \\
\text { Farmer }(\%)\end{array}$} & \multicolumn{6}{|c|}{ Crops (Region) } \\
\hline & $\begin{array}{c}\text { Corn } \\
\text { Nebraska/ } \\
\text { South Dakota } \\
(1986)\end{array}$ & $\begin{array}{c}\text { Soybeans } \\
\text { Nebraska/ } \\
\text { South Dakota } \\
(1986)\end{array}$ & $\begin{array}{c}\text { Wheat } \\
\text { Nebraska } \\
\text { South Dakota) } \\
\text { (1986) } \\
\text { (Frequencies in Pe }\end{array}$ & $\begin{array}{l}\text { Sugarcane } \\
\text { Louisiana } \\
(1992) \\
\text { cent) }\end{array}$ & $\begin{array}{c}\text { Rice } \\
\text { Louisiana } \\
(1992)\end{array}$ & $\begin{array}{c}\text { Apples } \\
\text { British } \\
\text { Columbia } \\
(1992)\end{array}$ \\
\hline $9 / 10(90)$ & 0.06 & 0 & 0.18 & 0 & 0 & 13.3 \\
\hline $17 / 20(85)$ & 0 & 0 & 0 & 0 & 0 & 40.0 \\
\hline $5 / 6(83.3)$ & 0 & 0 & 0 & 38.6 & 0 & 0 \\
\hline $4 / 5(80)$ & 0.18 & 0 & 0.18 & 47.1 & 0 & 26.7 \\
\hline $2 / 3(67)$ & 25.9 & 16.2 & 49.2 & 0 & 5.7 & 20.0 \\
\hline $3 / 5(60)$ & 34.1 & 45.4 & 20.6 & 1.4 & 51.4 & 0 \\
\hline $1 / 2(50)$ & 35.6 & 35.1 & 24.1 & 0 & 8.6 & 0 \\
\hline
\end{tabular}

Sources: See Data Appendix. The shares do not sum to $100 \%$ because there are other shares not reported. This is especially true of Louisiana rice where we find 35 different share terms, including 10 that have at least $2.9 \%$ of the contracts.

share also increases. We test this proposition two ways. First, we examine different crops, which often require different amounts of inputs over the course of the production cycle. Second, we examine the effect of input sharing on cropshare terms. When inputs are shared the number of unshared inputs falls to two and, therefore, the lower bound falls to onehalf (Proposition 3).

In the introduction table 2 showed that cropshare terms varied widely across regions, but the table concealed the variety of crops grown in these regions. States and regions vary a great deal in the variety of crops grown. $^{25}$ Table 5 shows the distribution of shares for corn, soybeans, and wheat in the Nebraska-South Dakota data, for rice and

\footnotetext{
${ }^{25}$ For example, in Illinois agriculture is very homogeneous. For the 10 crop years beginning in 1991, corn and soybeans comprised an average of $89 \%$ of the harvested cropland acreage in Illinois. (See the 2001 Illinois Annual Survey, Illinois Agricultural Statistics Service, http://www.agstats. state.il.us/annual/2001/tochtm.htm (accessed April 12, 2002)). In fact, no other state is as homogeneous as Illinois in terms of crop production. The 1997 Census of Agriculture shows the following percentages in corn and soybeans for the states in table 1: Illinois $92 \%$, Kansas $24 \%$, Louisiana 44\%, Nebraska 66\%, and South Dakota 44\%. British Columbia's largest crop fraction is hay at $36 \%$. Statistics Canada (1997), tables 4.1-4.10.
} 
sugarcane in the Louisiana data, and for apples in the British Columbia data. The striking feature of these data is that the shares for the crops in the three columns on the right are so much higher than the shares for the crops in the first three columns. In NebraskaSouth Dakota, there are three dominant shares $(1 / 2-1 / 2,3 / 5-2 / 5$, and $2 / 3-1 / 3)$ that account for over $90 \%$ of all share contracts. For the crops from Louisiana and British Columbia, however, there are almost no 50-50 contracts, and higher shares split between 4/5, 5/6, and 17/20.

Clearly, the distribution of shares depends on the type of crop grown. Had different crops been selected, different distributions of shares would have emerged. Generally speaking, when corn, soybeans, or other row crops are grown $50-50$ is common, but when wheat and other small grains are grown the $2 / 3$ share is more common. For fruit, like apples, pears, and peaches, the shares are usually $4 / 5$ or higher for the farmer. And for sugarcane, shares are at least 4/5.

Corn, soybeans, and wheat (the three crops on the left) generally involve fewer inputs/tasks than sugarcane, rice, and apples (the three crops on the right). ${ }^{26}$ Sugarcane, due to the sensitivity of the product during harvest, requires the farmer to be more involved in processing. Rice involves more tasks because of water management, and fruit requires so many tasks related to pruning and weeding the farms are seldom larger than 20 acres. Proposition 2 states that the more tasks involved the higher is the lower bound on the share equation and the higher the equilibrium shares. Table 5 is consistent with this.

Table 5 suggests that the lower bound on shares depends on the number of inputs, but it does so only because crop type can be used to approximate the number of inputs. A better test of the relationship between the lower bound and the number of inputs can be performed by exploiting differences in input sharing. None of the data presented thus far has controlled for the allocation of input costs (e.g., seed, fertilizer, pesticides) between the contracting parties. Table 6 shows frequency distributions for share terms, controlling for crops and for the allocation of input costs for corn and soybeans grown in Nebraska and South Dakota in the 1986 crop year. This is the only data set we have with detailed information on input sharing. In Nebraska and South Dakota,

\footnotetext{
${ }^{26}$ See Allen and Lueck (2002) for a detailed discussion of the different tasks involved in these crops.
}

unlike Illinois, corn and soybeans are often irrigated. ${ }^{27}$ The data shown in table 6 provide strong evidence for Proposition 3 because when the inputs are shared the 50-50 contract dominates. Table 6 also shows the frequency distribution of cropshare terms for these same crops when inputs are not shared. The distinction between contracts with and without input sharing is striking. When inputs are not shared the 50-50 contract falls from the dominant type to third place after $3 / 5$ and $2 / 3$. In fact, barely $20 \%$ of the contracts are $50-50$. In the introduction table 3 showed the distribution of shares for Northern and Southern Illinois, found in Young and Burke. In the north input costs are likely shared whereas in the south they likely are not shared. ${ }^{28}$

\section{Discrete Shares versus Continuous Cash Rents}

Proposition 4 says that cropshare contracts will be discrete and unchanging with respect to economic fundamentals because share contracts have a built-in adjustment. In order to test this proposition, we need to see how a change in one of the fundamentals changes the share and rent. Unfortunately most land attributes are unobservable. Our test of Proposition 4, however, exploits the fact that one land attribute is perfectly observable: total acres. As the size of the contracted land increases, the land becomes more valuable. With a cash rent contract we would (obviously) expect the total amount of rent paid to the landowner to increase. With a share contract, however, with its built-in adjustment, we expect no change in the share. We test this hypothesis with OLS regressions to estimate the determinants of contract terms, using either the total cash rent or share as the dependent variable. These regression estimates for three regional data sets are shown in table 7 . In all specifications the estimates

\footnotetext{
27 These contract terms are not presented in table 5 but are almost identical to the distribution for dry land corn and soybeans.

${ }^{28}$ Young and Burke's data (tables 1 and 2, p. 565) suggest a correlation between input and output sharing. In an unpublished companion paper (Burke and Young 2001, p. 7) also note that: "In the north, over $86 \%$ of the contracts are $(1 / 2,1 / 2)$ [that is, the output share is $1 / 2$ and the input share is also $1 / 2]$. In the south, about $39 \%$ of the contracts are of the form $(3 / 5,1)$ or $(2 / 3,1)$; fully $79 \%$ of the contracts use either $3 / 5$ or $2 / 3$ as the tenant's share of output and $3 / 5,2 / 3$, or 1 as the tenant's share of input." We consulted the source of the Illinois data used by Young and Burke and found that the northern regions share inputs $96 \%$ of the time, whereas in the southern region this occurs only 33\% of the time The 1995 Cooperative Extension Service Farm Leasing Survey (Department of Agricultural and Consumer Economics, University of Illinois, 1996). Hence, it seems that the distribution of shares in the two regions of Illinois reflects the dramatic differences in input sharing between those two regions.
} 
Table 6. Cropshare Frequencies by Crop and Input Cost Allocation

\begin{tabular}{|c|c|c|c|c|c|c|}
\hline Inputs Shared? & $\begin{array}{l}\text { Corn } \\
\text { Nebraska } \\
\text { South } \\
\text { Dakota } \\
\text { Yes }\end{array}$ & $\begin{array}{l}\text { Soybeans } \\
\text { Nebraska } \\
\text { South } \\
\text { Dakota } \\
\text { Yes }\end{array}$ & $\begin{array}{c}\text { Corn/ } \\
\text { Soybeans } \\
\text { Illinois } \\
\text { North } \\
\text { Region } \\
\text { Likely Shared }\end{array}$ & $\begin{array}{l}\text { Corn } \\
\text { Nebraska } \\
\text { South } \\
\text { Dakota } \\
\text { No }\end{array}$ & $\begin{array}{l}\text { Soybeans } \\
\text { Nebraska } \\
\text { South } \\
\text { Dakota } \\
\text { No }\end{array}$ & $\begin{array}{c}\text { Corn/ } \\
\text { Soybeans } \\
\text { Illinois } \\
\text { South } \\
\text { Region } \\
\text { Not Likely Shared }\end{array}$ \\
\hline \multicolumn{7}{|c|}{ Share To Farmer (\%) } \\
\hline $3 / 4(75)$ & 0 & 0 & 0 & 1.2 & 0.6 & 0 \\
\hline $2 / 3(67)$ & 8.3 & 3.6 & 1.7 & 28.3 & 15.7 & 53.5 \\
\hline $3 / 5(60)$ & 16.6 & 17.4 & 2.3 & 60.1 & 73.7 & 31 \\
\hline $1 / 2(50)$ & 69.7 & 74.6 & 94.8 & 6.8 & 6.1 & 14 \\
\hline
\end{tabular}

Sources: Data Appendix. The Nebraska and South Dakota data only show dryland crops for a better comparison with Illinois. The Illinois data are reported in Young and Burke (2001, figure 3, p. 562) and are derived from The 1995 Cooperative Extension Service Farm Leasing Survey (Department of Agricultural and Consumer Economics, University of Illinois, 1996).

Table 7. OLS Regressions (Dependent Variables: Cash Rent or Share)

\begin{tabular}{|c|c|c|c|c|c|c|}
\hline \multirow[b]{3}{*}{ Variables } & \multicolumn{6}{|c|}{ Data Set } \\
\hline & \multicolumn{2}{|c|}{$\begin{array}{c}\text { Nebraska/ } \\
\text { South Dakota } \\
\text { (1986) }\end{array}$} & \multicolumn{2}{|c|}{$\begin{array}{l}\text { Louisiana } \\
\text { (1992) }\end{array}$} & \multicolumn{2}{|c|}{$\begin{array}{c}\text { British } \\
\text { Columbia } \\
\text { (1992) }\end{array}$} \\
\hline & Cash & Share & Cash & Share & Cash & Share \\
\hline Acres $(1,000 \mathrm{~s})$ & $\begin{array}{r}3,104.04 \\
\quad(23.97)\end{array}$ & $\begin{array}{c}-0.38 \\
(-1.56)\end{array}$ & $\begin{array}{c}64.00 \\
(12.34)\end{array}$ & $\begin{array}{r}0.001 \\
(0.94)\end{array}$ & $\begin{array}{l}18.02 \\
(3.03)\end{array}$ & $\begin{array}{c}-0.01 \\
(-0.46)\end{array}$ \\
\hline \multicolumn{7}{|l|}{ Control Variables } \\
\hline Constant & $\begin{array}{r}-798.68 \\
(-2.53)\end{array}$ & $\begin{array}{c}65.68 \\
(109.18)\end{array}$ & $\begin{array}{l}53.38 \\
(2.50)\end{array}$ & $\begin{array}{l}19.26 \\
(7.18)\end{array}$ & $\begin{array}{l}14.02 \\
(0.47)\end{array}$ & $\begin{array}{l}33.70 \\
(4.51)\end{array}$ \\
\hline Hay & $\begin{array}{c}466.94 \\
(1.08)\end{array}$ & $\begin{array}{c}0.11 \\
(0.24)\end{array}$ & $\begin{array}{l}-2.23 \\
(-0.05)\end{array}$ & $\begin{array}{l}17.98 \\
(3.13)\end{array}$ & $\begin{array}{c}-7.57 \\
(-0.54)\end{array}$ & $\begin{array}{l}-0.45 \\
(-0.10)\end{array}$ \\
\hline Density & $\begin{array}{c}3.44 \\
(2.26)\end{array}$ & $\begin{array}{c}-0.01 \\
(-2.45)\end{array}$ & $\begin{array}{l}-0.17 \\
(-1.16)\end{array}$ & $\begin{array}{c}0.03 \\
(0.59)\end{array}$ & & \\
\hline Family & $\begin{array}{r}-497.86 \\
(-1.44)\end{array}$ & $\begin{array}{c}-0.28 \\
(-0.75)\end{array}$ & $\begin{array}{c}-3.84 \\
(-0.36)\end{array}$ & $\begin{array}{c}0.47 \\
(0.41)\end{array}$ & $\begin{array}{c}-3.55 \\
(-0.17)\end{array}$ & $\begin{array}{c}-1.14 \\
(-0.28)\end{array}$ \\
\hline Row crop & $\begin{array}{r}1263.77 \\
(2.76)\end{array}$ & $\begin{array}{c}-4.31 \\
(-8.54)\end{array}$ & $\begin{array}{c}-1.80 \\
(-0.19)\end{array}$ & $\begin{array}{c}2.37 \\
(1.78)\end{array}$ & $\begin{array}{c}8.68 \\
(0.29)\end{array}$ & $\begin{array}{l}-17.43 \\
(-2.10)\end{array}$ \\
\hline Rice & & & $\begin{array}{l}12.76 \\
(0.89)\end{array}$ & $\begin{array}{c}4.49 \\
(2.18)\end{array}$ & & \\
\hline Irrigated & $\begin{array}{r}1840.35 \\
(4.32)\end{array}$ & $\begin{array}{c}0.52 \\
(1.14)\end{array}$ & $\begin{array}{l}30.29 \\
(2.62)\end{array}$ & $\begin{array}{c}2.69 \\
(1.31)\end{array}$ & $\begin{array}{c}9.37 \\
(0.66)\end{array}$ & \\
\hline Age & & & $\begin{array}{c}-1.21 \\
(-3.29)\end{array}$ & $\begin{array}{c}-0.04 \\
(-0.97)\end{array}$ & $\begin{array}{c}-0.15 \\
(-0.27)\end{array}$ & $\begin{array}{c}0.42 \\
(0.28)\end{array}$ \\
\hline Institution & & & $\begin{array}{l}-14.72 \\
(-1.03)\end{array}$ & $\begin{array}{c}2.02 \\
(1.17)\end{array}$ & $\begin{array}{l}28.79 \\
(1.79)\end{array}$ & $\begin{array}{c}-8.30 \\
(-0.95)\end{array}$ \\
\hline Input shared & & $\begin{array}{c}-7.21 \\
(-17.61)\end{array}$ & & & & \\
\hline$R^{2}$ & 0.38 & 0.04 & 0.74 & 0.21 & 0.68 & 0.16 \\
\hline$F$ & 88.83 & 14.11 & 20.98 & 5.44 & 5.38 & 1.65 \\
\hline$N$ & 1,007 & 2,423 & 76 & 211 & 79 & 28 \\
\hline
\end{tabular}

Sources: See Data Appendix.

are consistent with our prediction. In the cash rent samples the coefficient estimate for total acres is always large, positive, and significant. In the cropshare sample, the coefficients are small and statistically insignificant. For example, in the South Dakota-Nebraska sample an increase of 1,000 acres in a cash rent contract leads to a large and statistically significant 
increase of $\$ 3,104$ in the total cash rent payment. However, the same change in acreage only leads to a statistically insignificant $0.38 \%$ change in the share. The change in cash rent is obvious, but our main point is that there is no change in the share when a land attribute (total acreage) changes.

\section{Changes in Moral Hazard}

Proposition 1 implies that the optimal discrete share term will depend on the degree of moral hazard present. This prediction can be tested by linking information on crop production to the data on cropshare terms. Recent studies have indicated that some crops are more prone to land use moral hazard in land attributes than others. ${ }^{29}$ For example, row crops like corn, soybeans, and sugar beets all require cultivation, which gives the farmers access to exploit the soil with various tillage techniques. Likewise, nonirrigated crops also provide more incentive and opportunities for farmers to exploit the moisture of the soil. These crops are more likely to be cropshared, and we further expect these crops to have lower shares. That is, as $m$ increases, the optimal share given in equation (6) falls. Table 8 presents the frequency of cropshare terms for two extreme cases for opportunities for moral hazard, conditional on a cropshare contract being used. The table shows the shares for these two crops. Dryland row crops allow easy access to manipulate soils. These crops are most often cropshared. Irrigated nonrow crops allow fewer opportunities for soil manipulation, and are more often cash rented. As can be seen from the table, the former have much lower shares than the latter, consistent with our model, which predicts as $m$ increases, the share to the farmer falls. Evidence from the regression estimates shown in table 7 are also consistent with this. In table 7 the coefficients from the share regressions show that row crops have lower shares for the farmer. Similarly irrigated crops are more likely to have higher cropshares.

\section{Conclusion}

We have explained the practice of using simple fractions in share contracts and continuous payments in cash rent contracts by

\footnotetext{
${ }^{29}$ See Allen and Lueck (2002) for a summary of this literature.
}

Table 8. Shares Based on Degree of Moral Hazard

\begin{tabular}{lrrrr}
\hline & \multicolumn{4}{c}{ Frequency of Shares } \\
\cline { 2 - 5 } & $50-50$ & $60-40$ & $67-33$ & $75-25$ \\
\hline Dryland row crops & 33.3 & 34.4 & 26.9 & 0.5 \\
$\begin{array}{l}\text { Irrigated nonrow } \\
\quad \text { crops }\end{array}$ & 17.0 & 5.3 & 51.1 & 18.1 \\
\hline
\end{tabular}

examining the incentives involved in both contracts. Our explanation used a multiple moral hazard model, combined with competitive assortative matching between landowners and farmers. This approach challenges the longheld idea these long-lived contractual practices are customs whether viewed as rules of thumb practiced because they were practiced in the past or as solutions to a coordination problem. Instead our approach implies these practices survive because sharing without side payments in a competitive environment is simple and robust.

Our model generated a sharing formula that led to simple fractions. This theory not only explains discrete sharing with simple fractions, it also explains why cash rent contracts are not this way, why shares move from one fraction to another, and why share contracts appear inflexible. Our data from four regions and time periods strongly supported the predictions of the model. As Romer (1984, p. 727) noted: "The existence and persistence of [such] customs is perfectly consistent with maximizing behavior [and]... we can analyze these customs using conventional economic tools." In this case we have shown that some simple modifications of contract theory can lead to a compelling explanation of customary agricultural practices that have puzzled economists for almost two centuries.

$$
\begin{aligned}
& \text { [Received June 2008; } \\
& \text { accepted March 2009.] }
\end{aligned}
$$

\section{References}

Ackerberg, D., and M. Botticini. 2002. "Endogenous Matching and the Empirical Determinants of Contract Form." Journal of Political Economy 110(3):564-91.

Akerlof, G. 1980. "A Theory of Social Custom of Which Unemployment May Be One Consequence." Quarterly Journal of Economics 94:749-75. 
Akerlof, G., and J. Yellen. 1985. "Can Small Deviations From Rationality Make Significant Differences to Economic Equilibria?" American Economic Review 75(4):708-20.

Allen, D. 1992. "What Does She See In Him: The Effect of Sharing on the Choice of Spouse." Economic Inquiry 30(1):57-67.

Allen, D., and D. Lueck. 1993. "Transaction Costs and the Design of Cropshare Contracts." RAND Journal of Economics 24(1):78-100.

- 2002. The Nature of the Farm: Contracts, Risk, and Organization in Agriculture. Cambridge, MA: MIT Press.

Allen, F. 1985. "On the Fixed Nature of Sharecropping Contracts." The Economic Journal 95(377):30-48.

Bardhan, P. 1984. Land, Labor, and Rural Poverty: Essays in Development Economics. New York: Columbia University Press.

Barzel, Y. 1997. Economic Analysis of Property Rights, 2nd ed. Cambridge: Cambridge University Press.

Blair, R., and F. Lafontaine. 2005. The Economics of Franchising. Cambridge: Cambridge University Press.

Burke, M., and H.P. Young. 2001. "Contractual Uniformity and Factor Returns in Agriculture." Unpublished, Johns Hopkins University.

Carmona, J., and J. Simpson. 1999. "Rabassa Morta' in Catalan Viticulture: The Rise and Decline of a Long-Term Sharecropping Contract, 1670s-1920s." Journal of Economic History 59(2):290-315.

Eswaran, M., and A. Kotwal. 1985. "A Theory of Contractual Structure in Agriculture." American Economic Review 75:352-67.

Heady, E. 1952. Economics of Agricultural Production and Resource Use. New York: Prentice Hall.

Holmstrom, B., and P. Milgrom. 1991. "MultiTask Principal-Agent Analyses: Incentive Contracts, Asset Ownership, and Job Design." Journal of Law, Economics, and Organization 7:24-52.

Hsieh, C.T, and E. Moretti. 2003. "Can Free Entry be Inefficient? Fixed Commissions and Social Waste in the Real Estate Industry." Journal of Political Economy, 111(5):1076-122.

Lam, D. 1988. "Marriage Markets and Assortative Mating with Household Public Goods: Theoretical Results and Empirical Implications." The Journal of Human Resources 3(4):46287.

Neary, H., and R. Winter. 1995. "Optimal Shares in Bilateral Agency Contracts." Journal of Economic Theory 66(2):609-14.
Newberry, D., and J. Stiglitz. 1979. "Sharecropping, Risk-sharing, and the Importance of Imperfect Information." In J.A. Roumasset, J.-M. Boussard, and I. Singh, eds. Risk, Uncertainty and Agricultural Development. Berkeley: University of California Press.

Robertson, A. 1987. The Dynamics of Productive Relationships: African Share Contracts in Comparative Perspective. Cambridge: Cambridge University Press.

Romer, D. 1984. "The Theory of Social Custom: A Modification and Some Extensions." Quarterly Journal of Economics 99(4):717-27.

Schelling, T. 1960. The Strategy of Conflict. Cambridge: Harvard University Press.

Statistics Canada. 1997. Agricultural Profile of British Columbia. Catalogue no. 95-181-XPB, Ottawa.

Tsoodle, L.J., and C.A. Wilson. 2000. "Nonirrigated Crop-Share Leasing Arrangements in Kansas." Staff Paper no. 01-02, Department of Agricultural Economics, Kansas State University.

Young, H.P., and M.A. Burke. 2001. "Competition and Custom in Economic Contracts: A Case Study of Illinois Agriculture." American Economic Review 91(3):559-73.

\section{Data Appendix}

\section{Nebraska and South Dakota Data}

The data from Nebraska and South Dakota come from the 1986 Nebraska and South Dakota Leasing Survey. The Leasing Survey was conducted by Professor Bruce Johnson of the University of Nebraska and Professor Larry Jannsen of South Dakota State University. The survey was funded by the Economic Research Service of the United States Department of Agriculture. A summary of the study and the survey procedures can be found in Bruce Johnson, Larry Jannsen, Michael Lundeen, and J. David Aitken, Agricultural Land Leasing and Rental Market Characteristics: A Case Study of South Dakota and Nebraska (report prepared for the Economic Research Service of the United States Department of Agriculture, 1988). There are 3,430 contract observations.

\section{British Columbia Contract Data}

Data for the 1979 British Columbia landownerfarmer contracts come from the British Columbia Ministry of Agriculture Lease Survey. This survey was conducted by the Farm Management group in the Vernon, British Columbia office of the Ministry. The survey was done by telephone and included farmers from throughout the province; however, farmers in the Okanagan Region were over-sampled. The number of usable responses was 
378. This survey asked few questions and thus has fewer variables.

\section{British Columbia and Louisiana Contract Data}

Data for the landowner-farmer cropshare contracts come from The 1992 British Columbia Farmland Ownership and Leasing Survey, which we conducted in January 1993. The survey was sent to a random sample of 3,000 British Columbia farm operators. The number of usable responses was 460 . The data are organized so that observations are individual contracts. Data for the landowner-farmer cropshare contracts come from The 1992 Louisiana Farmland Ownership and Leasing Survey, which we conducted in January 1993. The survey was sent to a random sample (chosen by the parish USDA County Agents) of 5,000 Louisiana farm operators. The number of usable responses was 530. The data are organized so that observations are individual contracts. Unlike the Nebraska/South Dakota data, these data do not have detailed information on landowners or input sharing. It does have information on ownership of land and other assets. The 1,004 different farms that make up the British Columbia and Louisiana sample are often arranged in various ways to create different data sets. 